\title{
Prioritization of municipalities' strategies for sustainable income and financing
} resources

Alireza Eslambolchi

Assistant Professor and Faculty Member, Hamedan Branch, Islamic Azad University, Hamedan, Iran

alireza.slambolch@gmail.com

\section{Alireza Emami}

Instructor and faculty member, Malayer Branch, Islamic Azad University, Malayer, Iran EmamiAlireza@Malayerau.ac.ir

Narges Jozei

PhD Student of Public Administration, Hamedan Branch, Islamic Azad University, Hamedan, Iran

n.jozei@gmail.com

Fakhraddin Maroofi

Associate Professor and Faculty Member of Kurdistan University, Sanandaj, Iran maroofi2900@uok.ac.ir

\section{Editor Científico: José Edson Lara}

Organização Comitê Científico

Double Blind Review pelo SEER/OJS

Recebido em 19.03.2018

Aprovado em 22.05.2018 


\title{
Prioritization of municipalities' strategies for sustainable income and financing
} resources

\begin{abstract}
The present applied, structural and survey-based study provides a new conceptual model and makes use of indirect longitudinal observations over the timeline of 20112015 and the research data collected from 57 known elites including university instructors, experts, municipality managers and, members of the Islamic-council in addition to the application of the AHP method in order to explore, prioritize and select suitable strategies for securing municipalities' sustainable income and financial resources. Furthermore, research questions about the inequality of the competent main and subsidiary strategies' statuses in terms of strategic planning of sustainable income and financial resources of municipalities are elaborated on while prioritization of the former strategies for achieving the mentioned resources is completed using the Freedman test, student's t-test and, the AHP method in the SPSS software. The priorities of strategies for obtaining sustainable income and financial resources in the municipality of the city of Malayer include: amendment of the structure of municipalities' sustainable income and financial resources system as the $1^{\text {st }}$ priority with an average weight of 0.2620 ; strategic management of sustainable income and financial resources as the $2^{\text {nd }}$ priority with an average weight of 0.2249 .
\end{abstract}

Keywords: Sustainable income; strategic planning; income resources; financial resources; income strategy.

\section{Priorização das estratégias dos municípios para recursos sustentáveis de renda e financiamento}

\section{Resumo}

O presente estudo aplicado, estrutural e baseado em pesquisa, fornece um novo modelo conceitual e faz uso de observações longitudinais indiretas sobre a linha de tempo de 2011-2015 e os dados de pesquisa coletados de 57 elites conhecidas, incluindo instrutores universitários, especialistas, gerentes municipais e membros de o conselho islâmico, além da aplicação do método AHP, a fim de explorar, priorizar e selecionar estratégias adequadas para garantir a renda sustentável e os recursos financeiros dos municípios. Além disso, são elaboradas questões de pesquisa sobre a desigualdade dos status das estratégias principais e subsidiárias competentes em termos de planejamento estratégico de renda sustentável e recursos financeiros dos municípios, enquanto a priorização das estratégias anteriores para alcançar os recursos mencionados é completada usando o teste Freedman, teste t de estudante e o método AHP no software SPSS. As prioridades das estratégias para obtenção de 
renda e recursos financeiros sustentáveis no município da cidade de Malayer incluem: alteração da estrutura do sistema de renda e recursos financeiros sustentáveis dos municípios como a primeira prioridade com peso médio de 0,2620; gestão estratégica de renda sustentável e recursos financeiros como a segunda prioridade com um peso médio de 0,2249.

Palavras-chave: Renda sustentável; planejamento estratégico; recursos de renda; recursos financeiros; estratégia de renda.

\section{Priorización de las estrategias de los municipios para obtener ingresos sostenibles y recursos de financiación}

\section{Resumen}

El presente estudio aplicado, estructural y basado en encuestas proporciona un nuevo modelo conceptual y hace uso de observaciones longitudinales indirectas sobre el cronograma de 2011-2015 y los datos de investigación recopilados de 57 élites conocidas, incluidos instructores universitarios, expertos, gerentes de municipios y miembros de el consejo islámico, además de la aplicación del método AHP con el fin de explorar, priorizar y seleccionar estrategias adecuadas para asegurar el ingreso sostenible de los municipios y los recursos financieros. Además, se desarrollan preguntas de investigación sobre la desigualdad de los estados de estrategias principales y subsidiarias competentes en términos de planificación estratégica de ingresos sostenibles y recursos financieros de los municipios, mientras que la priorización de las estrategias anteriores para lograr los recursos mencionados se completa con la prueba de Freedman. la prueba t de Student y el método AHP en el software SPSS. Las prioridades de las estrategias para obtener ingresos sostenibles y recursos financieros en el municipio de la ciudad de Malayer incluyen: la modificación de la estructura del sistema de ingresos y recursos financieros sostenibles de los municipios como la primera prioridad con un peso promedio de 0.2620; gestión estratégica de ingresos sostenibles y recursos financieros como la segunda prioridad con un peso promedio de 0.2249 .

Palabras clave: Ingresos sostenibles; planificación estratégica; recursos de ingresos; recursos financieros; estrategia de ingresos.

\section{Introduction}

Nowadays, managers' minds are more than ever occupied by thoughts about resource restrictions against abundant consumptions; the issue of selection and 
prioritization according to policies and plans while taking into account the costs of economic opportunities and, social preferences.

In many countries, although that there are sufficient resources available, but as a result of failure in exploring a desirable strategy for securing sustainable financial resources in the process of municipal strategic planning, a failure is witnessed in the context of providing suitable and desirable services to the citizens as the actual beneficiaries, in addition to a reduced efficiency in providence as well as increased economic, social and cultural fluctuations.

Determining sustainable income resources for municipalities includes foreseeing the future status and preparing the organization for providing citizens with desirable services as well as, confronting the challenges in a dynamic environment that works as a bridge between the present and the future (Ibrahimi et al., 2015). The trend of changes in municipalities' income resources in the past period exhibits a lack of development of central characteristics including lack of continuous growth, selfefficacy, self-reliance and lack of suitable performance-related and structural solidarity (Zarabi et al., 2013).

Due to increased environmental dynamicity, nonstop changes in functions of cities, transfer of the costs of economic opportunity of decisions and the resulting negative effects on urban identity, emergence of capitalism elements, growth of population, low cost- efficiency of municipal services, lack of possibility of shutting down municipal services, increased fixed and unavoidable costs and etc.

In the modern and postmodern eras have oriented the municipalities' structures of income resources towards reliance on selling densities, fines relating to the article100 committee and other unsustainable income resources (Ziari et al., 2014). Due to lack of proper policies and unsuitable bureaucratic structures including lacking a specific minister for making macro-level decisions, we are witnessing a nonexistence of a long-term vision on issues including setting policies for securing sustainable income and financial resources in municipalities.

As a result urban management related issues are overlooked by short-term visions and therefore the instability of incomes of municipalities have severely affected the provision of suitable municipal services as well as the suitability of distribution of services (Rafieian \& Raad, 2014). On this basis, in order to mitigate municipal problems and to perform an efficient management of services, it is necessary to 
determine the restrictions of financial resources, prioritize the financing options and, to consider the costs of commercial opportunities in strategic planning so that a sustainable financing resource is secured.

According to the proposed conceptual model, the strategies for development of financing resources of municipalities include: 1 - improvement of the participation of the private sector and having a sustainable economic development; 2-amendment of the structure of municipalities' income system; 3- amendment of the structure of Municipalities' system of detection and collection of taxes; 4- borrowing and grants and; 5-strategic management of resources.

\subsection{Goals}

The purpose of exploration and determination of a suitable strategy for securing sustainable income and financial resources for municipalities is to improve competitiveness, efficiency, effectiveness of resources, the final desirability of the last spent monetary currency, citizens' welfare and, enhancement of urban management.

The strategy of securing sustainable income and financing resources for municipalities pursues the enhancement of the performance of urban management on the basis of sustainability of municipalities' income and financing resources; and evaluates the former on the basis of factors such as sustainable economic growth, enhancement of the participation of private sector, amendment of the structure of municipalities' income system, amendment of the structure of municipalities' system of detection and collection of taxes, borrowing and grants and, strategic management of resources.

Considering the variability of the criterions of strategies for development of sustainable income for municipalities, any decision must be based on multi-criteria decision making along with determination of priorities. Prioritization of the main and secondary strategies for development of sustainable sources of income through the application of AHP is one of the main goals of the present study.

In other words, by trying to realize the current status and to illustrate the goals based on potential facilities in addition to determining a proper way of achievement in the process of planning, we are trying to propose an integrated systematic method for making logical policies and making gradual changes in order to determine what could 
be done for achievement of goals in future and how can an undesirable future be prevented (Dire, 2015).

On the other hand, considering the variability of citizens' preferences in the manners of receiving services and the high expectations of citizens from municipality managers, it seems that it is not possible to secure their welfare and interests without adherence to economic principles and rules (Pajoovan, 2015). In addition, in public organizations the nature of management is based on income-expense management and therefore in the process of strategic planning it is necessary to have strategic thinking and, explore and or create suitable and desirable strategies for securing sustainable financing resources (Khalili SH, 2014).

Considering the 38 inherent duties of municipalities (Zarabi \& Mohammadi, 2015), in order to prevent conflicts in goals, plans, strategies and policies, it is necessary to prepare plans, perform a proper management and, execute strategically, it is necessary to improve the efficiency of urban management while mitigating the waste of resources (Aghazadeh \& Zomorodian, 2015).

\section{Review of the Literature}

Zarabi, Saberi \& Mohamadi (2015) conducted a study titled as "prioritization of city development strategies using the AHP method", and made an effort to prioritize the city development strategies through the application of the analytic hierarchy process. they found out that for the city of Isfahan, the macro city development strategies include 6 strategies namely as "basic organization and spatial form"; "dynamicity of urban economy"; "social viability"; "sustainable access"; "improvement of environmental quality" and; "proper governance". There are also 38 subsidiary or secondary strategies that are illustrated in a hierarchical form.

Rahnama et al., (2014) carried out a research study under the title of "creating perspectives for the city of Osnoie through the process of city development strategies. They have introduced the CDS (city development strategies) process as a novice approach in urban planning while considering the process of perspective creation as the heart of the former process. These authors have adopted a descriptive method and considered the following four points while determining the perspective: 1- recognition of the current status of the city; 2- inspection of both downstream and upstream 
designs; 3-global and domestic experiences and; 4-surveying the people. One weakness of this study is that it ignores the processes of strategic management and strategic thinking while tending to make decisions based on the existing conditions and structures while also considering a fixed environment.

Mahmoudi et al., (2014) carried out a research study titled as "investigation and prioritization of the factors associated with sustainable incomes of the municipality of Tehran". They have introduced the following as the four most important and effective factors providing the municipality of Tehran with sustainable incomes in respect of importance: 1- increased rate of land taxes; 2- the Tehran's municipality's system of detection and collection of taxes; 3 - financial relationships between the state and the municipality of Tehran and; 4- access to monetary-financial markets.

Sharzei \& Majed (2015) have stated that a large portion of the incomes of Iran's municipalities are not consistent with the notions of sustainability and desirability while being mostly supplied by unsustainable resources. This is while sustainable resources such as renovation taxes, land taxes and income generated from selling services have remained relatively passive.

Wade \& Wade (2015) elaborated on creative financing methods in India's urban infrastructures based on private and public participation while considering taxes as the main instrument in constitution of municipal financing market. From the view of Bred et al., (2014), the growing trend of the need for public urban services necessitates the use of resources such as borrowing from banks; physical development costs; selling land and; collaboration. Nektacham (2015) believes that the role of urban local bureaus in financing the civil projects of India through creative methods is highly effective. These methods include: various taxes and local bills; green taxes; grants from international banks; simultaneous attraction of participation of the private and public sectors in investments.

Vladimir Vadok (2013) wrote a paper titled as "strategic planning in Russia's municipalities and comparing it with the municipalities of Northern Europe" and stated that as a result of issues such as goal conflicts between the local and state governments in addition to low rates of public participation as well as cultural issues and, lack of regulations aiming at stimulation and execution of strategic planning, 
Russia has not been much successful compared to Northern European countries including Norway, Sweden and, Finland.

Based on the statistics published by the UN, in terms of social, tax-related, budgeting and, public participation benefits, Russia is in the $50^{\text {th }}$ place. Therefore the author has concluded in his paper that conflicts between the goals of managers and the external environment are sources of reduction of public participation and improper realization of the incomes of municipalities and local governments.

Smith (2013) wrote a paper under the title of "strategic planning in municipalities of Irving, Texas" and stated that proper sustainable finance and income strategies have been developed for most of the cities of U.S; however no strategic execution is evident yet. Due to the continuance and suitable execution timing of the strategic plans, the performances of local governments in terms of efficiency, effectiveness, quality of services and, performance have increased which has resulted in development of more operational budgets in addition to improvement of employees' motivations, improved public satisfaction and, efficient allocation of resources.

Based on conducted surveys, $90 \%$ of the respondents have stated that the determined priorities of strategies are already suitable; on the other hand $89 \%$ of the respondents have maintained that determination of the priorities of strategies results in more desirable services and more profits. Nonetheless, $70 \%$ of the respondents have considered the former as the element of financial sustainability and efficiency of operational designs.

In this paper it has been stated that citizens are effective as beneficiary groups. However, social structures and policies of securing municipalities' sustainable sources of income in America are totally different than Iran. 


\subsection{Conceptual Model}

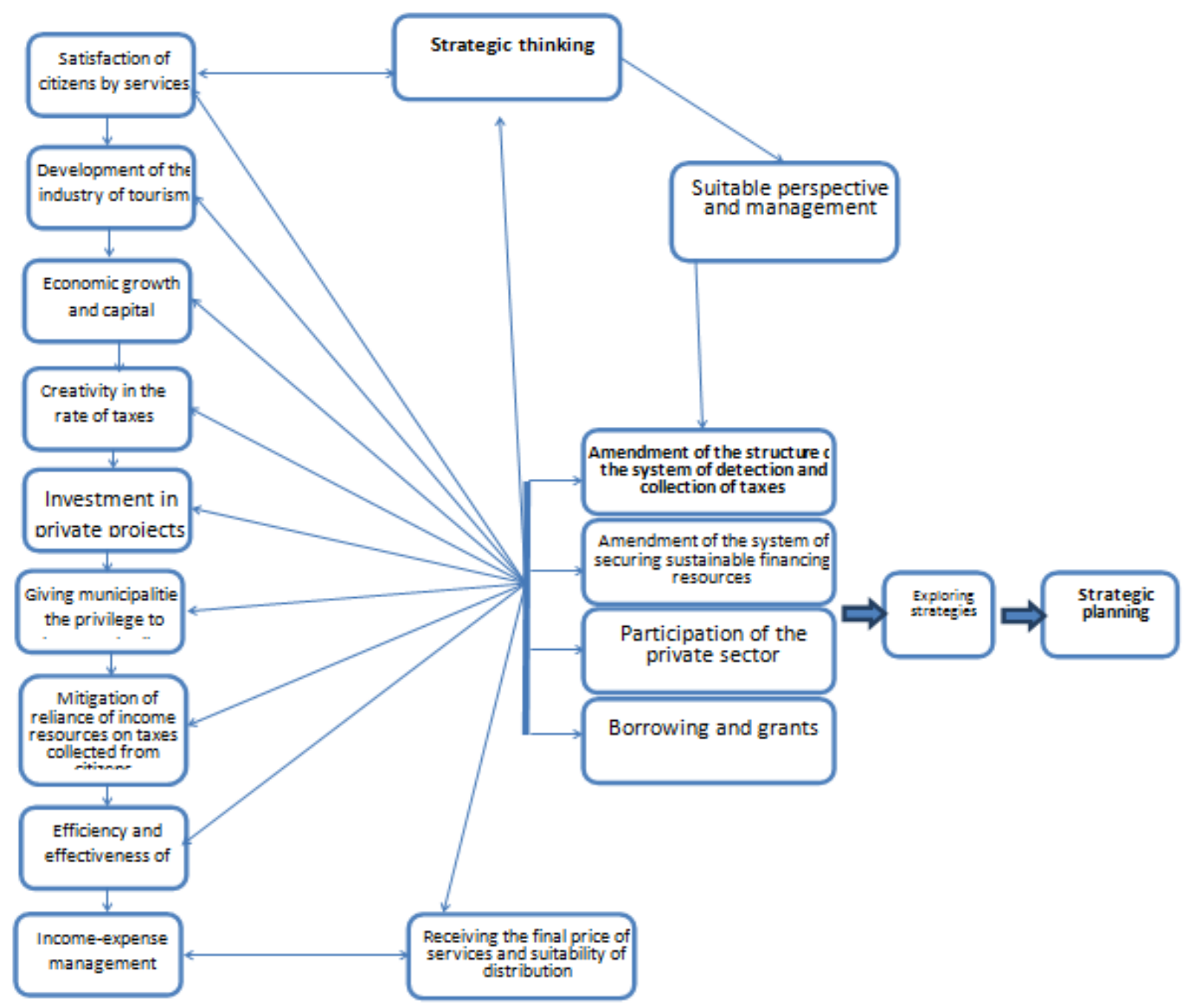

Figure 1

The conceptual model

\subsection{Research questions and hypotheses}

\subsubsection{Main research question:}

Which of the strategies of 1-participation of private sector; 2- amendment of the structure of municipalities' income system; 3- amendment of the structure of municipalities' system of detection and collection of taxes; 4- borrowing and grants and; 5-strategic management of sustainable resources of income of municipalities is 
of a higher importance and priority, and what are the priorities of their associated secondary strategies in terms of creation of sustainable income resources

\subsubsection{Subsidiary research question:}

Are the weights and importance of strategies effective in creating sustainable income and financing resources for municipalities equal?

\section{Scope of the Study}

The geographic territory of the study is limited to the city of Malayer as a southern city in the province of Hamadan. In addition, the years studied in the research are from 2011 to 2015.

\subsection{Methods}

The method of this research is descriptive-survey, which is applied in a field method. The research community consisted of 57 experts including university professors, experts, municipal directors, and members of the Islamic Council. A questionnaire was used to collect information. In order to achieve the desired outlook and realization of strategic planning, it is necessary to identify, prioritize and select appropriate strategies for financing of the sustainable municipality's revenue and resources. The validity of the questionnaire was confirmed by the professors. Data were analyzed by SPSS software, Friedman test, t-student and AHP method.

\section{Results}

In order to answer the question asking whether the weights and importance of strategies effective in creating sustainable income and financing resources for municipalities equal or not, we will use the Freedman test to decide upon the importance of each factor. The hypotheses are:

- H0: the average scores of factors effective on securing sustainable income resources for municipalities are equal.

- H1: at least the average scores of two factors effective on securing sustainable income resources for municipalities are not equal.

The following results were yielded from the SPSS software: 
Table 1

Results of tests on the 5 main factors and 18 items

\begin{tabular}{l|l|l|l|l}
\hline $\begin{array}{l}\text { Freedman test } \\
\text { statistic }\end{array}$ & $\begin{array}{l}\text { Number of } \\
\text { samples }\end{array}$ & Freedom degree & significance & Test result \\
\hline 435.889 & 57 & 4 & 0.000 & H0 rejected \\
\hline
\end{tabular}

\section{Table 2}

Results of tests on five effective indexes on securing sustainable income resources for the municipality of Malayer

\begin{tabular}{l|l|l|l|l}
\hline $\begin{array}{l}\text { Freedman test } \\
\text { statistic }\end{array}$ & $\begin{array}{l}\text { Number of } \\
\text { samples }\end{array}$ & Freedom degree & significance & Test result \\
\hline 45.944 & 57 & 4 & 0.000 & H0 rejected \\
\hline
\end{tabular}

Tables 1 and 2 show statistics of the Chi-Do value, number of observations, freedom degree and the minimum significance value for the statuses of 18 factors and 5 main indices. Considering the fact that the significance value is smaller than 0.05 , the $\mathrm{HO}$ hypothesis stating that the average scores of factors effective on securing sustainable income resources for municipalities are equal is rejected.

In other words, a significant difference exists between the statuses of factors. The validity of the incorporated questionnaire was approved by related experts and scholars and, the reliability of the former was approved through the application of the Cronbach's alpha coefficient method.

The obtained Cronbach's alpha coefficient is $82 \%$ which is a value larger than $7 \%$ and therefore, it was accepted. The data collected through the questionnaires were fed into the SPSS software. Since the input data were qualitative, the analyses were also performed using qualitative methods including the K-S and the Student's $t$ test.

$2^{\text {nd }}$ question: what is the status of these indices in the municipality of Malayer?

For this question, a questionnaire based on the AHP method was distributed among the former population of 57 individuals in which the respondents were asked to provide a score to each main strategy and sub-criterion in the conceptual model of the study in order to determine the most preferred factors. The geometric average of each 
answer was calculated and afterwards, the Expert Choice software was used to calculate the weights of each main and subsidiary strategy. With respect to the objectives, each criterion is analyzed and prioritized.

\subsection{Weighting the criterions and sub-criterions}

In order to determine the importance factor of each criterion and sub-criterion, the AHP method is used and pair comparisons are made. The former paired comparisons are carried out in order to calculate the correspondence rate from the 9point scale of Alsatian. All the criterions are compared in pairs. The respondents were asked to provide the scores based on the following table:

Table 3

The 9-point scale of Alsatian

\begin{tabular}{l|l|l|l|l|l|l}
\hline Score & 1 & 3 & 5 & 7 & 9 & $2-4-6-8$ \\
\hline definition & $\begin{array}{l}\text { Equal } \\
\text { preference }\end{array}$ & $\begin{array}{l}\text { Preferred a } \\
\text { little }\end{array}$ & $\begin{array}{l}\text { Preferred } \\
\text { more }\end{array}$ & $\begin{array}{l}\text { Preferred } \\
\text { much more }\end{array}$ & $\begin{array}{l}\text { Perfectly } \\
\text { preferred }\end{array}$ & $\begin{array}{l}\text { Other } \\
\text { preferences }\end{array}$ \\
\hline
\end{tabular}

Table 4

The paired comparison results

\begin{tabular}{l|l|l|l|l|l}
\hline Private sector & $\begin{array}{l}\text { Amendment } \\
\text { of the } \\
\text { structure of } \\
\text { tax detection } \\
\text { and } \\
\text { collection }\end{array}$ & $\begin{array}{l}\text { Borrowing } \\
\text { and grants }\end{array}$ & $\begin{array}{l}\text { Strategic } \\
\text { management } \\
\text { of resources }\end{array}$ & $\begin{array}{l}\text { Amendment } \\
\text { of the } \\
\text { structure of } \\
\text { the income } \\
\text { system }\end{array}$ & criterions \\
\hline 2 & 2 & 2 & 1 & 1 & $\begin{array}{l}\text { Amendment } \\
\text { of the } \\
\text { structure of } \\
\text { the income } \\
\text { system }\end{array}$ \\
\hline 2 & 1 & 2 & 1 & 1 & $\begin{array}{l}\text { Strategic } \\
\text { management } \\
\text { of resources }\end{array}$ \\
\hline 0.5 & 1 & 1 & 2 & 3 & $\begin{array}{l}\text { Borrowing } \\
\text { and grants }\end{array}$ \\
\hline 0.5 & 1 & 0.5 & 1 & $\begin{array}{l}\text { Amendment } \\
\text { of the }\end{array}$ \\
\hline
\end{tabular}




\begin{tabular}{l|l|l|l|l|l}
\hline & & & & & $\begin{array}{l}\text { structure of } \\
\text { tax detection } \\
\text { and collection }\end{array}$ \\
\hline 0.5 & 0.5 & 0.3 & 0.5 & 1 & $\begin{array}{l}\text { Private sector } \\
\text { participation }\end{array}$ \\
\hline
\end{tabular}

Considering the above table it can be concluded that the importance of the amendment of the structure of system of municipal income is twice the borrowing and grants and the same fashion, the importance of strategic management of resources is twice the participation of private sector. In other words, participation of private sector is as half important as strategic management of resources in securing sustainable income and financing resources for municipalities. The present study has made use of the relative weight calculation method in addition to the AHP method due to its higher precision (Tables 5 and 6).

\section{Table 5}

Calculation of geometric averages

\begin{tabular}{l|l}
\hline $\begin{array}{l}\text { Strategic management of resources } \\
((1)(1)(2)(1)(2)(4))^{\frac{1}{5}}=1.5874\end{array}$ & $\begin{array}{l}\text { Amendment of the income system's structure } \\
((1)(1)(2)(2)(2)(5))^{\frac{1}{5}}=1.8493\end{array}$ \\
\hline $\begin{array}{l}\text { Amendment of the structure of tax detection and } \\
\text { collection system }\end{array}$ & Borrowing and grants \\
$((0.5)(1)(0.5)(1)(2)(4))^{\frac{1}{5}}=1.1224$ & $((0.5)(1)(2)(3)(4))^{\frac{1}{5}}=1.5131$ \\
\cline { 2 - 2 } & $\begin{array}{l}\text { Participation of the private sector } \\
\end{array}$ \\
& $((0.5)(0.5)(0.3)(0.5)(1)(1))^{\frac{1}{5}}=0.5888$
\end{tabular}

The importance factors are calculated through normalization of the above numbers. In this fashion, each value is divided by the sum of scores. 


\section{Table 6}

Calculating the importance factors of criterions

\begin{tabular}{l|l}
\hline Strategic management of resources & Amendment of the income system's structure \\
$w 1=\frac{1.5074}{7.0579}=0.2249$ & $w 1=\frac{1.8493}{7.0579}=0.2620$ \\
\hline $\begin{array}{l}\text { Amendment of the structure of tax detection and } \\
\text { collection system }\end{array}$ & $\begin{array}{l}\text { Borrowing and grants } \\
w 1=\frac{1.5888}{7.0579}=0.0834\end{array}$ \\
\cline { 2 - 2 }$w 1=\frac{1.5131}{7.0579}=0.2144$ & $\begin{array}{l}\text { Participation of the private sector } \\
\end{array}$ \\
&
\end{tabular}

The following presents the importance factors of the rest of sub-criterions of the three best criterions. In addition the entire phases of determination of the importance factors of criterions will be pointed out.

\section{Table 7}

Paired comparison of sub-strategies of the strategy of amendment of the structure of tax detection and collection systems

\begin{tabular}{l|l|l|l|l|l|l|l}
\hline Criterions & 1 & 2 & 3 & 4 & 5 & 6 & 7 \\
\hline Delegation of the task of detection and collection of taxes & 1 & 2 & 3 & 5 & 4 & 5 & 5 \\
\hline $\begin{array}{l}\text { Determination of the total area of urban lands and } \\
\text { respective taxes }\end{array}$ & 0.5 & 1 & 2 & 3 & 4 & 5 & 5 \\
\hline Determination of the citizens' tax burden capacity & 0.25 & 0.5 & 1 & 1 & 4 & 4 & 7 \\
\hline $\begin{array}{l}\text { Using e-services in collection of taxes under the light of } \\
\text { public participation }\end{array}$ & 0.33 & 0.33 & 1 & 1 & 3 & 6 & 4 \\
\hline $\begin{array}{l}\text { Receiving the final cost of urban services considering the } \\
\text { capacity of tax burden }\end{array}$ & 0.25 & 0.25 & 0.25 & 0.33 & 1 & 3 & 4 \\
\hline Distribution of urban services in different areas & 0.2 & 0.2 & 0.25 & 0.17 & 0.33 & 1 & 1 \\
\hline Enforcement of collection & 0.2 & 0.2 & 0.14 & 0.25 & 0.25 & 1 & 1 \\
\hline
\end{tabular}

As it is evident in the above table, the sub-strategies of delegation of the task of collection of taxes has received the number 3 and this is a sign that the delegation of the task of collection of taxes to municipalities is three times more important that the sub-strategy of determination of citizens' tax burden capacity. In the analyses, It was indicated that sub-criterions of the strategy of amendment of the structure of the system 
of tax detection and collection and, the enforcement of collection have the lowest importance.

\section{Table 8}

Paired comparison of the sub-strategies of the strategy of amendment of the structure of the system of income

\begin{tabular}{|c|c|c|c|c|c|c|}
\hline Criterions & $\begin{array}{l}\text { Development } \\
\text { of the } \\
\text { tourism and } \\
\text { eco-tourism } \\
\text { industries }\end{array}$ & $\begin{array}{l}\text { Creativity } \\
\text { in tax } \\
\text { bases } \\
\text { and rates }\end{array}$ & $\begin{array}{l}\text { Creativity } \\
\text { in } \\
\text { creation } \\
\text { of new } \\
\text { markets }\end{array}$ & $\begin{array}{l}\text { Amendment } \\
\text { and } \\
\text { promotion of } \\
\text { the share of } \\
\text { VAT, income } \\
\text { and } \\
\text { consumption }\end{array}$ & $\begin{array}{l}\text { Gradual } \\
\text { replacement } \\
\text { of } \\
\text { unsustainable } \\
\text { sources with } \\
\text { sustainable } \\
\text { sources of } \\
\text { income }\end{array}$ & $\begin{array}{l}\text { Attraction } \\
\text { of } \\
\text { investors } \\
\text { and } \\
\text { promotion } \\
\text { of } \\
\text { investment } \\
\text { in private } \\
\text { designs }\end{array}$ \\
\hline $\begin{array}{l}\text { Development } \\
\text { of the tourism } \\
\text { and eco- } \\
\text { tourism } \\
\text { industries }\end{array}$ & 1 & 1 & 4 & 3 & 5 & 5 \\
\hline $\begin{array}{l}\text { Creativity in } \\
\text { tax bases and } \\
\text { rates }\end{array}$ & 1 & 2 & 4 & 4 & 6 & 7 \\
\hline $\begin{array}{l}\text { Creativity in } \\
\text { creation of } \\
\text { new markets }\end{array}$ & 0.25 & 0.25 & 1 & 2 & 7 & 2 \\
\hline $\begin{array}{l}\text { Amendment } \\
\text { and } \\
\text { promotion of } \\
\text { the share of } \\
\text { VAT, income } \\
\text { and } \\
\text { consumption }\end{array}$ & 0.33 & 0.25 & 0.50 & 1 & 4 & 1 \\
\hline $\begin{array}{l}\text { Gradual } \\
\text { replacement } \\
\text { of } \\
\text { unsustainable } \\
\text { sources with } \\
\text { sustainable } \\
\text { sources of } \\
\text { income }\end{array}$ & 0.20 & 0.17 & 0.14 & 0.25 & 1 & 1 \\
\hline $\begin{array}{l}\text { Attraction of } \\
\text { investors and } \\
\text { promotion of } \\
\text { investment in } \\
\text { private } \\
\text { designs }\end{array}$ & 0.20 & 0.20 & 0.50 & 1 & 1 & 1 \\
\hline
\end{tabular}

According to the above matrix, the value of the sub-strategy of innovation and creativity in tax basis and rates is 6 times more important than the sub-strategy of gradual replacement of unsustainable sources with sustainable sources of income. 
Table 9

Paired comparison of the sub-strategies of strategic management of resources

\begin{tabular}{|c|c|c|c|c|c|c|}
\hline Criterions & $\begin{array}{l}\text { Developme } \\
\mathrm{nt} \\
\text { strategic of } \\
\text { planning for } \\
\text { sustainable } \\
\text { sources of } \\
\text { income and } \\
\text { financing }\end{array}$ & $\begin{array}{l}\text { Efficiency } \\
\text { and } \\
\text { effectiveness } \\
\text { of resources }\end{array}$ & $\begin{array}{l}\text { Organizatio } \\
\text { nal health }\end{array}$ & $\begin{array}{l}\text { Participatio } \\
n \text { of } \\
\text { beneficiarie } \\
\text { s }\end{array}$ & $\begin{array}{l}\text { Mitigation of } \\
\text { the costs of } \\
\text { economic } \\
\text { opportunitie } \\
\text { s }\end{array}$ & $\begin{array}{l}\text { Prioritizatio } \\
n \text { of optimal } \\
\text { allocation of } \\
\text { resources }\end{array}$ \\
\hline $\begin{array}{l}\text { Development } \\
\text { of strategic } \\
\text { planning for } \\
\text { sustainable } \\
\text { sources of } \\
\text { income and } \\
\text { financing }\end{array}$ & 3 & 3 & 3 & 3 & 3 & 1 \\
\hline $\begin{array}{l}\text { Efficiency } \\
\text { and } \\
\text { effectiveness } \\
\text { of resources }\end{array}$ & 3 & 2 & 3 & 1 & 1 & 0.33 \\
\hline $\begin{array}{l}\text { Organization } \\
\text { al health }\end{array}$ & 3 & 2 & 1 & 1 & 1 & 0.33 \\
\hline $\begin{array}{l}\text { Participation } \\
\text { of } \\
\text { beneficiaries }\end{array}$ & 3 & 2 & 1 & 1 & 0.33 & 0.33 \\
\hline $\begin{array}{l}\text { Mitigation of } \\
\text { the costs of } \\
\text { economic } \\
\text { opportunities }\end{array}$ & 3 & 1 & 0.5 & 0.5 & 0.25 & 0.33 \\
\hline $\begin{array}{l}\text { Prioritization } \\
\text { of optimal } \\
\text { allocation of } \\
\text { resources }\end{array}$ & 3 & 1 & 0.5 & 0.25 & 0.2 & 0.33 \\
\hline
\end{tabular}

As it is evident in table 9, the sum of importance factors of the mentioned six-fold criterions is equal to 1 and this shows the relativity of the importance of criterions. In the following table, the value of 3 is assigned to the sub-strategy of prioritization of optimal allocation of resources and therefore, in the present study this sub-strategy is of a higher relative importance compared to other sub-strategies and therefore a higher importance factor is assigned to it. Development of strategic planning for sustainable sources of income and financing is illustrated in the first phase of the hierarchical tree and afterwards, other sub-strategies are compared in the form of the above table in 
pairs. Sub-strategies are highly variable and a specific weight coefficient has been assigned to each of them.

With respect to the goals of the study, the sub-strategies' scores are mixed in order to calculate the overall score of the main strategy. The following table represents 10 strategies for development of securing sustainable sources of income for municipalities towards development of a strategic planning.

\section{Table 10}

Rankings of the main and secondary strategies of securing sustainable sources of income for the municipality of Malayer

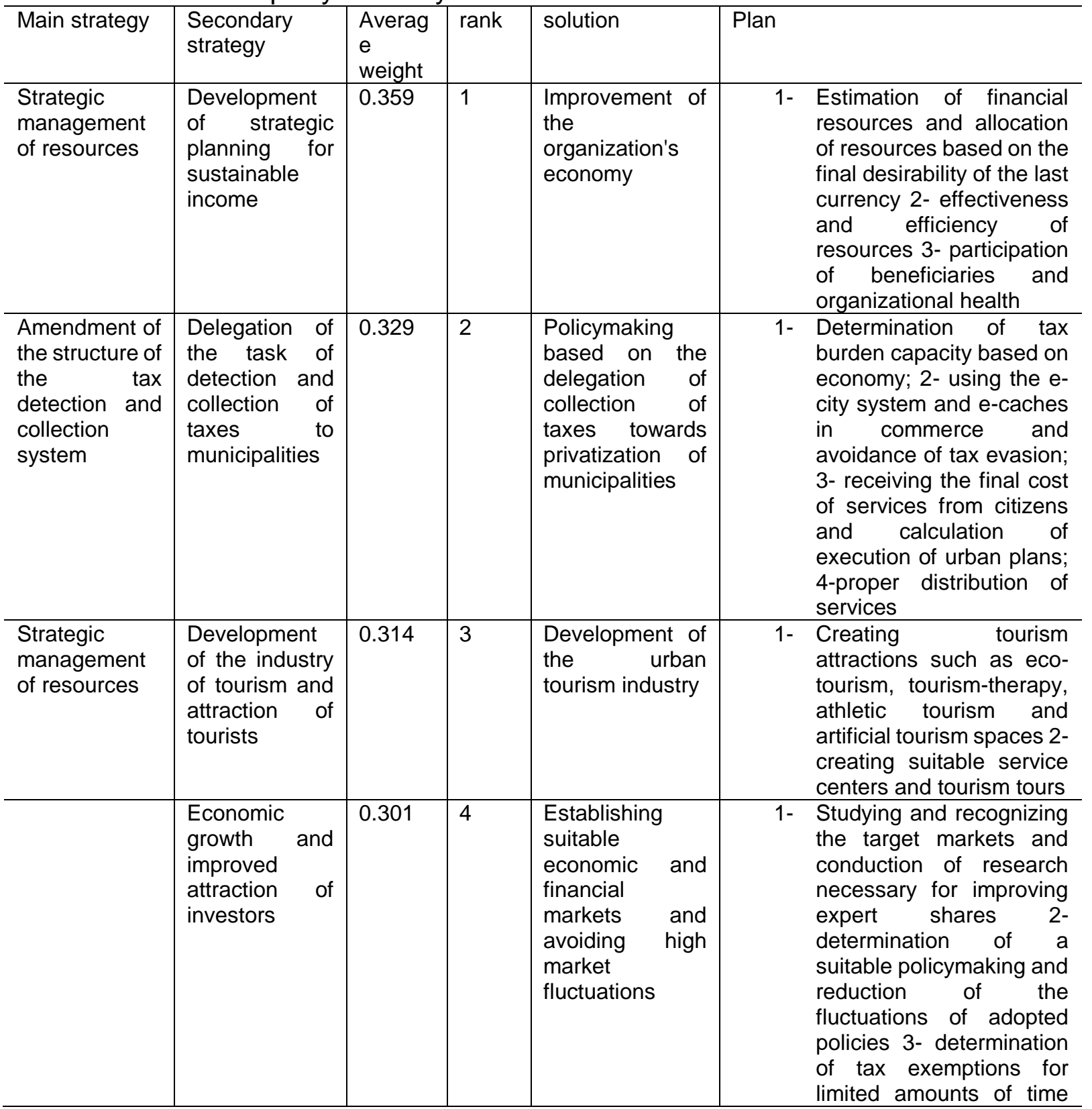




\begin{tabular}{|c|c|c|c|c|c|}
\hline $\begin{array}{l}\text { Participation of } \\
\text { the private } \\
\text { sector }\end{array}$ & & & & & $\begin{array}{l}\text { and in return for complete } \\
\text { satisfaction of } \\
\text { commitments }\end{array}$ \\
\hline $\begin{array}{l}\text { Amendment of } \\
\text { the structure of } \\
\text { municipal } \\
\text { income } \\
\text { systems }\end{array}$ & $\begin{array}{l}\text { Creativity in } \\
\text { tax bases and } \\
\text { rates }\end{array}$ & 0.286 & 5 & $\begin{array}{l}\text { Proposing } \\
\text { suitable tax base } \\
\text { and rates }\end{array}$ & $\begin{array}{l}\text { Considering a suitable rate of tax } \\
\text { on consumption }\end{array}$ \\
\hline $\begin{array}{l}\text { Participation of } \\
\text { the private } \\
\text { sector }\end{array}$ & $\begin{array}{l}\text { Economic } \\
\text { growth and } \\
\text { improved } \\
\text { investment }\end{array}$ & 0.275 & 6 & $\begin{array}{lr}\begin{array}{l}\text { Economic } \\
\text { evaluation }\end{array} \\
\text { plans } \\
\text { optimal } \\
\text { allocation } \\
\text { resources }\end{array}$ & $\begin{array}{l}\text { 1-Economic evaluation of plans } \\
\text { and determination of their priorities } \\
\text { with respect to resource limitations } \\
\text { 2- optimal allocation of resources } \\
\text { based on the final desirability of } \\
\text { the last spent currency }\end{array}$ \\
\hline $\begin{array}{l}\text { Borrowing and } \\
\text { grants }\end{array}$ & Selling bonds & 0.254 & 7 & $\begin{array}{l}\text { Selling bonds for } \\
\text { private designs }\end{array}$ & $\begin{array}{l}\text { 1- Proposing plans that are } \\
\text { economically justifiable 2- } \\
\text { investment of the income } \\
\text { yielded from the sales in } \\
\text { economic plans that at } \\
\text { least have a return equal } \\
\text { to the cost of economic } \\
\text { opportunity }\end{array}$ \\
\hline $\begin{array}{l}\text { Amendment of } \\
\text { the structure of } \\
\text { the system of } \\
\text { tax detection } \\
\text { and collection }\end{array}$ & $\begin{array}{l}\text { Receiving the } \\
\text { final cost of } \\
\text { services }\end{array}$ & 0.2368 & 8 & $\begin{array}{l}\text { Receiving the } \\
\text { cost of services }\end{array}$ & $\begin{array}{l}\text { 1- Collection of taxes from } \\
\text { citizens based on their } \\
\text { consumption and and } \\
\text { exploitation of services } \\
\text { and the VAT } \\
\text { 2- } \begin{array}{l}\text {-taxes on lands and } \\
\text { properties }\end{array}\end{array}$ \\
\hline $\begin{array}{l}\text { Strategic } \\
\text { management } \\
\text { of resources }\end{array}$ & $\begin{array}{l}\text { Efficiency and } \\
\text { effectiveness } \\
\text { of resources }\end{array}$ & 0.2367 & 9 & $\begin{array}{l}\text { Paying attention } \\
\text { to returns and } \\
\text { the return rate in } \\
\text { addition to } \\
\text { making optimal } \\
\text { choices }\end{array}$ & $\begin{array}{l}\text { Organizational training; 2- } \\
\text { development of strategic } \\
\text { planning and budgeting } \\
\text { based on goals }\end{array}$ \\
\hline $\begin{array}{l}\text { Strategic } \\
\text { management } \\
\text { of resources }\end{array}$ & $\begin{array}{l}\text { Prioritization of } \\
\text { optimal } \\
\text { allocation of } \\
\text { resources }\end{array}$ & 0.2366 & 10 & $\begin{array}{l}\text { Paying attention } \\
\text { to the costs of } \\
\text { economic } \\
\text { opportunities, } \\
\text { decisions and } \\
\text { economic } \\
\text { evaluation }\end{array}$ & $\begin{array}{l}\text { 1-paying attention to the rule of } \\
\text { desirability of the last spent } \\
\text { currency; 2-having strategic } \\
\text { thinking and a desirable } \\
\text { perspective in addition to creation } \\
\text { of desirable strategies }\end{array}$ \\
\hline
\end{tabular}

\section{Conclusions and suggestions}

According to our analyses in the present study, the priorities of strategies for obtaining suitable perspectives and sustainable development of financial resources of municipalities are as follows: amendment of the structure of municipalities' sustainable 
income and financial resources system as the 1st priority with an average weight of 0.2620; strategic management of sustainable income and financial resources as the 2nd priority with an average weight of 0.2249 ; amendment of the structure of the system of detection and collection of taxes as the 3rd priority with an average weight of 0.2146 ; participation of the private sector as the 4th priority with an average weight of 0.159 and; borrowing and grants as the 5 th priority with an average weight of 0.0834 .

In addition, among the sub-strategies comprising the above mentioned five main strategies the priorities are as follows: development of strategic planning for securing sustainable sources of income with an average weight of 0.359 as $1^{\text {St }}$ priority; the strategy of delegation of the task of detection and collection of taxes with an average weight of 0.329 as the $2^{\mathrm{Nd}}$ strategy; the strategy of development of the industry of tourism as the $3^{\text {Rd }}$ strategy with an average weight of 0.314 ; economic growth and improved investment with an average weight of 0.301 as the $4^{\text {Th }}$ priority; creativity and innovation in tax base and rates as the $5^{\text {Th }}$ priority with an average weight of 0.286 ; promotion of investment in municipal resources with an average weight of 0.275 as the $6^{\text {Th }}$ priority; selling bonds with an average weight of 0.254 as the $7^{\text {Th }}$ priority; receiving the final cost of services from citizens with an average weight of 0.2368 as the $8^{\text {Th }}$ priority; efficiency and effectiveness of resources with an average weight of 0.2367 as the $9^{\text {Th }}$ priority and; prioritization of optimal allocation of resources as the $10^{\text {Th }}$ priority.

Among the secondary strategies of securing sustainable sources of income and financing for municipalities, the strategy of receiving foreign loans and helps has obtained the lowest coefficient and therefore for the municipality of the city of Malayer, the criterions of development of strategic planning for securing sustainable income sources, delegation of the task of detection and collection of taxes to the municipality and development of the industries of tourism and eco-tourism in various historic, cultural, medicinal, educational and services sectors are emphasized more than others.

\subsection{Suggestions}

1- Since taxes play an important role in terms of securing sustainable sources of income for municipalities in developed countries, in future studies it is better to 
elaborate on suitable tax bases including consumption bases and the system of delegation of the task of tax detection and collection to municipalities as public organizations. in this way the efficiency of the tax system and the participation of citizens in payment increases.

2- Since collection of taxes by the Islamic Councils have been rejected based on the administrative justice court, future researchers must consider this limitation of financial resources in their studies.

3- In order to improve the efficiency of resources and to secure sustainable sources of income we are required to reject previous laws and issue protective laws towards municipalities, however since 1986, municipalities have been excluded from governmental devices but no supportive laws have been passed in order to secure sustainable sources of income and financing for municipalities of Iran.

\section{References}

Dire, P. (2012). Strategic Planning. Khalili Shourini Translation, Fourth Edition, Tehran, Department.

Ibrahimi, M., Mahdavi, A., \& Saremi, M. (2015). Survey of Tehran Municipality Revenues from the Viewpoint of Citizens. Journal of Urban Management Research, $18,1$.

Khalili Shourini, S. (2014). The Role of Finance in Strategic Planning in Mashhad. 4th International Conference on Urban Planning and Management, Mashhad, 22-34.

Mahmoudi, M., Zomorrodian, Gh., \& Aghaei, M. (2011). Investigating the factors related to Tehran's overtime revenues and prioritizing them. The First International Conference on Urban Economics, Tehran, 53-28.

Pejouyan, J. (2013). Public Finance in Urban Economics. Quarterly Journal of City Economics, 4(14), 22-29.

Rafiean, M., \& Shahin, R. M. (2014). City Development Strategy to Implement Urban Development Planning. Journal of Social Studies of Iran, 3(14), 6-29.

Rahnema, M., Shokoohi, M., \& Sharifi, B. (2014). City vision in the process of CDS urban development strategy. The 5th International Conference on Urban Planning. Mashhad, 64-48. 
Shojafi, Gh., Amiri, M., \& Mir Anayat, S. A. (2015). Study of the proportion of income sources and missions of the municipality studied in Tehran municipality. Journal of Economic and Management, 7, 28-12.

Vladimir, D. (2016). Strategic Planning At The Municipal Level: Russian Challen D Nordic Practices Ges An. Barents in institutions 76, Economies and politics, Strategic planning at the municipal level: Russian challenges and Nordic, 1, 75-95.

Zarabi, A., Mohammadi, J., \& Saberi, H. (2015). Prioritizing urban development strategies (CDS) using the AHP hierarchical process of studying the Isfahan metropolis. Quarterly Journal of Geographical Space, 12(39), 75-59.

Ziari, K., Mahdi, A., \& Behnamiri, M. (2014). Study and Recognition of Financial Resources and Providing Strategies for Improving the Sustainability of Municipality Revenues, Municipality of Mahabad. Urban Management - Urban and Rural Management Institute, 31, 124-107. 